\title{
Resilience in EU Discourse: A New Norm in Relations with Russia?
}

Elena B. Pavlova, Tatiana A. Romanova

\begin{abstract}
This article examines the impact of the crisis in Russia-EU relations on the European Union's articulation of the resilience concept and analyzes how its incorporation into the EU Global Strategy has affected the Brussels-Moscow relationship. Academic concepts of resilience and constructivism provided the theoretical basis for the research. The study of academic works made it
\end{abstract}

\author{
Elena B. Pavlova, Ph.D. (Political Science) \\ St. Petersburg University, Russia, Theory and History Department, Associate Professor; \\ Tartu University, Estonia, Senior Research Fellow \\ ORCHID: 0000-0001-6718-5167 \\ SPIN-RSCl: 9186-0180 \\ AuthorlD: 402845 \\ ResearcherID: Q-5485-2016 \\ Scopus ID: 56378344600 \\ Address: 1/3 Smolnogo Str., St. Petersburg, Russia 193060 \\ Tel. + 78123636435 (x 6175) \\ E-mail: e.pavlova@spbu.ru, elena.pavlova@ut.ee \\ Tatiana A. Romanova, Ph.D. (Political Science) \\ St. Petersburg University, Russia, Department of European Studies, Associate Professor \\ ORCHID: 0000-0002-5199-0003 \\ SPIN-RSCI: 8791-1970 \\ AuthorlD: 200093 \\ ResearcherID: J-6397-2013 \\ Scopus ID: 24779959300 \\ Address: 1/3 Smolnogo Str., St. Petersburg, Russia 193060 \\ Tel. + 78123636435 (x 6175) \\ E-mail: t.romanova@spbu.ru, romanova@mail.sir.edu
}

The study was conducted with the support of the grant from the Russian Science Foundation, Project \#17-18-01110. 
possible to identify basic characteristics of resilience. This is an analytical (not normative) attribute of any system, and it is focused on the resources needed to overcome threats rather than on threats as such, with both threats and resources being inherent in the system. The study of the European Union's discourse shows that it has interpreted of resilience as a new norm (ascribed to democratic regimes only), with emphasis on threats rather than resources. These differences were caused, among other things, by the ongoing crisis in relations between the EU and Russia. Resilience as a new norm allows the EU to emphasize Russia's "otherness" and thus assert its own identity as a normative leader. The focus on threats sets out a clear action plan for fighting threats associated with Russia. In Eastern Europe, resilience based on common threats emanating from Russia reinforces the EU's approach towards transformations launched in these countries earlier. So, despite its theoretical potential, resilience, as construed by the European Union, does not allow Russia and the EU to overcome the current crisis in their relations.

Keywords: resilience, Russia-EU relations, Eastern Europe, identity, normativity, securitization, EU external activities

The Five Guiding Principles for the relations with Russia (Mogherini, 2016) and particularly the European Union's Global Strat-

egy (Global Strategy, 2016) published in 2016 ushered in a new stage in relations between Moscow and Brussels. The idea of partnership and cooperation through dialogue has been replaced with the European Union's concept of resilience. Moreover, resilience has become a new normative trend in the European integration process and a key instrument in the EU's foreign policy. However, the new concept raises more questions than gives answers; its implementation remains a subject of serious debates among both academics and government officials.

The purpose of this article is to determine how the current crisis in relations between Moscow and Brussels has affected the European Union's articulation of its resilience concept and to consider its consequences for relations between the EU and Russia now and in the future. To begin with, we are going to define theoretical aspects of resilience necessary for analyzing political processes, including 
international ones, and compare them with the resilience concept proposed by the EU. After that we will briefly describe the current state of Russia-EU relations which presaged the emergence of this concept in Brussels' policy. Then we will take a look at a new round of the European Union's efforts to identify Russia as the "Other" challenging the EU's resilience, and analyze the specific use of the resilience concept amid the unfolding competition between Brussels and Moscow in the post-Soviet space. Finally, we will make some conclusions on the consequences the articulation of the resilience concept may have for relations between Russia and the EU.

\section{RESIELIENCE: SPECIAL THEORETICAL ASPECTS}

The concept of resilience was proposed in the 1970s by ecologist Crawford Holling who defined it as "a measure of the persistence of systems and of their ability to absorb change and disturbance and still maintain the same relationships between populations or state variables" (Holling, 1973 , p. 14). This definition became a starting point in academic debates on the essence of the concept. Born within the framework of natural sciences, the concept of resilience gradually evoked interest among representatives of the humanities as well, and now it is a subject of active interdisciplinary discussions. For example, this concept is used in studying the neoliberal economic system to explain the functioning of market mechanisms. Resilience is often mentioned in psychology and in ecological and urban planning projects. However, it gets the most attention in works analyzing crisis management issues. Also, references to resilience can often be found in analytical reports on humanitarian interventions and counter-terrorism.

What theoretical aspects of resilience can be identified as key ones, especially for the study of political systems and international relations? Firstly, resilience is regarded as a natural characteristic of any system. If a system is not resilient, it simply disappears. In other words, resilience is a norm for a system and has no ethical characteristics. It is neutral. Democracy is resilient, but, unfortunately, so is corruption in many systems.

Secondly, the focus is on the resources of resilience in a system; their accumulation or consolidation in response to challenges constitutes 
the subject of study within this set of theoretical approaches. This point is extremely important for political science, as it allows one to distinguish between different resilience concepts, on the one hand, and securitization, which puts emphasis on the articulation of threats and challenges, on the other.

Thirdly, the most difficult, but necessary, point for understanding resilience is the idea that both challenges and resources are generated by one and the same system, that is, there is virtually no dichotomy between the subject and the object. The importance of this point is that it makes it possible to separate the idea of resilience from potentially similar categories, such as 'resistance' or 'sustainability', and to emphasize the integrity of the system by identifying elements which, although opposed to each other, have a common origin.

Fourthly, any talk of resilience leads us to a single system where both challenges and resources for responding to them are solely internal in nature. But the systems being studied can be of different levels. For example, one can talk about internal challenges to society, the regime or the state or about internal challenges to the neoliberal world order. There are challenges to democracy within one state, and there are challenges to world democracy. But in any case, it is one system, and its resilience can be maintained only by internal resources.

The desire to understand the resilience of different societies has prompted extensive historical and sociopolitical research important for modern politics. It includes works which analyze, for example, the socioecological characteristics of resilience in East African societies over the past two centuries (Bollig and Anderson, 2017), and special issues of journals which focus on the resilience of Eastern Mediterranean societies in the 6th-17th centuries (Human Ecology, 2018). There are also works that study the resilience of authoritarian regimes, such as the People's Republic of China (Nathan, 2003; Li, 2012).

Furthermore, there are some very interesting studies showing how the established practices of social groups not only contribute to their resilience, but also provide resources for influencing higherlevel political processes. For example, J. Bakker, J. de Koning, and J. van Tatenhove studied the community of Scottish fishermen that 
influences public marine planning policies through mobilizing their resilience practices (Bakker et al., 2019). As Ana Juncos notes, "resilience thus operates a turn from the international to the local (governments, societies, organizations, and individuals)" (Juncos, 2018 , p. 562), that is, the use of this concept makes it possible to identify new resources for stability and security in a society.

So, resilience is not a new concept for politics. Academic discussions on its content and operationalization have been underway for at least a decade. Resilience, as stated in the introduction to a special issue of the Politics magazine, is primarily the "organizing principle in contemporary political life" (Brasset et al., 2013), where the security of the community, both local and global, is a core element of governance. The specificity of the resilience concept lies in the understanding and inevitability of crises in any system and the availability of internal resources for overcoming these crises. In the political sphere, it is about grassroots practices that support the system, which makes the issue of limits to governance from above a key point. Scholars are actively discussing how the state or the international community can stimulate grassroots practices in order to overcome a crisis without impairing the autonomy of their agents.

The key reference point is neoliberalism which is prevalent in the contemporary social order (Krüger, 2019). So one of the main directions in the study of resilience in political processes is the invocation of Michel Foucault's legacy and, above all, his concept of "governmentality," which demonstrates how modern power is molded by existing grassroots practices (Joseph, 2013; Mavelli, 2017). For example, Jon Coaffee and Pete Fussey explore the logic of supporting society's resilience against the threat of terrorism and emphasize the complexity and contradictions of grassroots practices used in people's cooperation with the governmental authorities (Coaffee and Fussey, 2015). There is often a paradoxical situation where elites appeal to the resilience concept while simultaneously emphasizing the responsibility of citizens for their own security and at the same time exclude them from the decision-making process, thus turning them into passive recipients (Rogers, 2013). This problem also exists at the international level, especially as part of humanitarian interventions. For example, Sarah Bracke argues that the 
use of outside practices for maintaining resilience can prove disastrous for countries subjected to external interference (Bracket, 2016).

This raises an important question: What is a system the resilience of which needs to be maintained in each particular case? In fact, when a threat is presented as an external element or when instruments of stability are brought in from the outside, we can hardly talk about the activation of internal resources.

Researchers also draw special attention to the relative similarity of such concepts as 'resilience' and 'securitization/de-securitization,' introduced into scientific discourse by the Copenhagen School. And although both concepts contribute to the study of security, there is a significant difference between them. As Philippe Bourbeau notes, any talk of resilience is always about determining its degree (Bourbeau, 2013). There are no completely resilient systems, and therefore it is a question of maintaining this quality of a system and finding appropriate resources for doing that. The focus is on resources. Securitization (just like de-securitization) is a purely discursive practice which focuses on threats to the reference object (not on the resources for overcoming them).

So the theory of resilience has already become an integral part of the discussion on the modern system of governance, where priority is given to critical reevaluation of its application in different regimes and societies. Moreover, by the time the Five Guiding Principles and the Global Strategy were published in the EU, the concept of resilience had already been actively used by international organizations (such as UN bodies and agencies and the OECD) and number of states, including individual EU countries (Treshchenkov, 2019). The essence of resilience was closely linked to existing theoretical studies. However, when the EU was introducing the concept of resilience, it chose to do it its own way in many respects. We will consider these distinctions in the next section.

\section{RESILIENCE AS AN EU NORM: THEORY IN ACTION}

The use of the term 'resilience' in Western political discourse has already become widespread, and that is why a legitimate question arises: Can we talk about such a concept at all? Could 'resilience' be just a catch 
word or another bureaucratic and spectacular stunt on the part of the European Union? In some cases, it really is. But this interpretation will not be correct for the European Union's official discourse. In this section of the article we will show how the concept is presented in numerous documents issued by Brussels and in popular works by EU analysts, which seek to explain what resilience actually is and how it has become part of the European Union's foreign and domestic political discourse.

The European Union's articulation of the resilience concept highlights its two main differences from the theoretical principles mentioned above. The first one is that Brussels formulates resilience as a new norm. The second one is that it emphasizes the threats to which both the EU and the third countries it supports must be resilient. Let's consider these differences in more detail.

In its Global Strategy, the EU makes it clear that resilience is linked to democratic development and, moreover, ensures it. The document emphasizes that "a resilient state is a secure state, and security is key for prosperity and democracy." In addition, "a resilient society featuring democracy, trust in institutions, and sustainable development lies at the heart of a resilient state" (Global Strategy, 2016). According to this and a number of other documents, the EU itself is an example of such a society. Moreover, Brussels declares its readiness to help other states and societies gain resilience. Its outreach extends to Central Africa in the south and Central Asia in the east.

The normative component has always been one of the main elements of the European Union's domestic and foreign policy. Suffice it to recall the Declaration on European Identity adopted in the 1970s, the inclusion of values in the text of the Maastricht Treaty, the adoption of the Charter of Fundamental Rights as well as various academic debates on the civil, ethical, and normative power Europe. Previously, however, the norms promoted by Brussels were borrowed from the European intellectual heritage, especially the Enlightenment. Today, the situation is different. European officials have borrowed the existing concept of resilience (including the one used in international practice) and filled it with new substance. As a result, resilience has become a norm of European integration along with democracy and human rights. The EU is turn- 
ing an analytical category into a normative one, and transferring the entire discussion on its maintenance from the operational level to the ideological one. In practical terms, the EU is reinforcing the promotion of democracy in its foreign policy with yet another norm-resilience.

Relations with Russia played a significant role in this new round of the European Union's efforts to assert its normative leadership. The logic of normative interaction supported by Brussels in recent decades involved not only the promotion of European norms, but also active involvement of other international actors in the normative discussion (Pavlova and Romanova, 2017). The norms themselves, which emerged within the framework of neoliberal ideology, envisaged gradual engagement of their recipients in the dialogue as full-fledged participants. This situation, on the one hand, contributed to Moscow's awareness of its own (potential) subjectivity as a recipient of these norms. On the other hand, this model of interaction called into question the EU's undisputed normative leadership on the global stage, as the new participants claimed the right to contest the EU's official position, have a say in the interpretation of norms, and apply them to specific events.

It was the decline of normative leadership that precipitated the emergence of the Global Strategy. Moreover, EU politicians hold that Russia fell short of expectations by claiming its right to interpret international norms. Therefore the pristine openness of the normative core is no longer justified. The adoption of the Global Strategy, as one of its authors, Nathalie Tocci, pointed out, was necessitated by a "deep existential crisis" and the desire of Europeans to see the EU as a stronger player in world politics (Tocci, 2016, p. 462). So, the main resource of the EU's resilience, both internally and globally, is the previously established norms and, as stated in the Global Strategy, its "enduring power of attraction." However, the concept of resilience registers the unidirectional dissemination of norms, as well as the EU's position as an unquestionable normative leader. And although the first glance at the Global Strategy gives the impression that the European Union is ready to opt for a more realist approach to foreign policy, a detailed analysis of the texts makes it clear that Brussels remains committed to normative hegemony. The declared principled pragmatism should 
be understood to mean a rethinking of previous experience and a rejection of the idea of open core for new players.

Another important difference between the EU's concept of resilience and existing academic debates is that Brussels focuses above all on challenges and threats against which such resilience must be mobilized, assuming that its "power of attraction" no longer requires serious revision. And again this refers to Russia in the first place. Many of its actions are labeled a challenge to resilience as a norm. Furthermore, opposition to Russia's foreign policy becomes a guarantee of resilience for both the European Union itself and its neighbors.

Eastern European and Baltic countries are playing a noticeable role in this strategy of determining Russia's behavior as a threat due to both historical heritage and their unambiguous position that the reincorporation of Crimea was an act of Russian aggression.

According to the Global Strategy, "peace and stability in Europe are no longer a given. Russia's violation of international law and the destabilization of Ukraine, on top of protracted conflicts in the wider Black Sea region, have challenged the European security order at its core" (Global Strategy, 2016). At the same time, while marking Russia's behavior as a common threat to the stability of the European Union and neighboring states, Brussels is also talking about specific challenges from Moscow. The EU Global Strategy indirectly, but a 2017 joint communication (Strategic Approach to Resilience, 2017) directly associates Moscow with such resilience threats as stable energy supply, fake news and strategic communication, as well as cyber risks. In 2018, this list was extended to include the use of chemical weapons and disproportionate activities of security services.

This creates an extremely interesting situation from both theoretical and practical points of view. In order to formulate its concept of resilience, the European Union essentially securitizes it, underscoring its validity and necessity through the articulation of potential threats coming, implicitly or explicitly, from Russia. The issue of resources is pushed into the background.

Thus, relations with Russia provided the basis for the emergence of the European Union's concept of resilience. In its discourse, it differs 
from the resilience theory in two ways: normativity which asserts the unquestionable leadership of EU, and the emphasis on threats, the source of which is often determined as Russia. Resilience here essentially loses its relevance as a tool for resolving crises, as it only records the status of one element in the system of relations with regard to challenges posed by another element.

\section{RUSSIA AS THE PERPETUAL "OTHER"}

The European Union's new foreign policy towards Russia, whereby the idea of threats posed by the latter to the resilience of the EU and its partners takes center stage, significantly changes the overall context of cooperation between Moscow and Brussels. The Global Strategy says that "the EU and Russia are interdependent", but notes that the EU intends to "engage Russia to discuss disagreements and cooperate if and when our interests overlap" (Global Strategy, 2016). The Five Principles advocate a similar view. Russia once again appears as "the Other," as an actor of world politics which shapes up its foreign policy strategy and international behavior according to principles different from those upheld by the EU.

Such a situation is nothing new for European/EU identity politics. It has already been described by many researchers, starting with Larry Wolff and Iver Neumann. However, today the focal point of opposition is Russia's specific activities recognized as a challenge to European norms and values. Russia's behavior is portrayed as that of "the Other," as proof of its "otherness" which can be overcome only if the Kremlin completely changes its agenda and accepts the European Union's norms as understood in the West. As a result, the perception of Russia as an actor in international relations which is seeking to undermine democratic resilience in the EU and neighboring territories is opening a new chapter in attempts to "exclude" Russia from the discussion on potential ways of solving European security and cooperation problems. This approach does not help to improve relations between Brussels and Moscow. Moreover, it leaves only one option, unacceptable to modern Russia, for resolving the current crisis in relations: unquestionable commitment to the European Union's initiatives. 
Interestingly, Russian civil society continues to be regarded as the target audience for promoting European norms. The idea of separating the resilience of states from the resilience of societies is clearly stated in the Global Strategy and the 2017 joint communication on resilience. The Five Guiding Principles also unambiguously state the EU's intention to build a dialogue with Russian civil society. By appealing to citizens, the EU draws attention to the universality of the norms it promotes, which should eventually allow Brussels to regain the position of unconditional normative leader in the region and the world. So, on the one hand, the EU stresses a chance for Russian citizens to return into the fold of Europe, but on the other hand, portrays Russia's political elites and leaders as the epitome of "the Other" viewed by the EU as "non-European" and undermining the security and prosperity of the region.

At the same time, the articulation of the concept of resilience as its integral norm suggests the stability of the European Union despite a number of difficult problems facing it. The Brexit, migration crisis, value differences within the European Union, the growing heterogeneity of member states and their priorities-all this, according to its documents, becomes only part of internal discussions obligatory in a free society. Serious challenges come from the outside, for example from Russia, and it is in their face that the EU demonstrates cohesion and unity defined as 'resilience.'

It is not accidental that in its reaction to the events in Salisbury, the EU referred to resilience but meant the solidarity and cohesion of its institutions and member states. This logic allows the EU to consolidate its unity against external and internal challenges. However, in our opinion, portraying Russia, more precisely its official elites, as "the ultimate Other" unable to change in principle, and putting this "Other" beyond the framework of normative interaction is a shortsighted approach. By destroying the previously built system, the European Union depicts Russia as a competitor in a more pronounced manner, thus calling into question the resilience of the entire system of relations in the region of Greater Europe. 


\section{RESILIENCE DISCOURSE IN THE STRUGGLE FOR REGIONAL LEADERSHIP}

Securitization of resilience and conceptualization of Russia as the "Other" allow the EU to increase its influence in the post-Soviet space amid confrontation with Moscow. A new stage of competition with Russia in the post-Soviet space is mentioned almost openly in the EU's documents concerning its new foreign policy agenda. Resilience still plays a major role here. "We will strengthen the EU, enhance the resilience of our eastern neighbors, and uphold their right to determine freely their approach towards the EU,' says the Global Strategy.

This phrase gives a clear picture of the situation in Eastern Europe. First of all, Brussels emphasizes its interest in and attention to processes in the post-Soviet space, where Russia's behavior is presented as a challenge to security and existing norms, as well as to the right of Eastern European countries to make their own choice. However, while Russia is branded as the "Other," the EU's eastern neighbors are defined differently and granted an opportunity to be "included" in the European system (with the EU as the center), provided they follow EU norms and maintain their resilience in the first place.

Secondly, the EU declares its readiness to help them and guarantee that they will be able to freely choose the degree of rapprochement with the EU. Russia appears rather implicitly in this idea of rapprochement. Nevertheless, it is quite obvious that it is competition with Moscow that prompts the EU to make such statements. Moreover, according to the EU, Eastern European countries are facing similar "Russian" challenges (stability of energy supply, disinformation, cyber threats), which produce an additional mobilization effect and become, as one of the EEAS officials has aptly remarked, a "resource of cooperation" (Personal Interview, 2018) between the EU and Eastern Neighborhood countries.

At the same time, resilience means the process of mobilizing internal capabilities. Therefore, such EU statements can be understood as an openly declared intention to actively participate in internal affairs of other countries so that they could build up their resilience. However, this policy can be viewed as interventionism (Juncos, 2016). But Brussels rejects such accusations, claiming that its purpose is to 
help civil society in these countries mobilize democratic resources that are positive by definition. At the same time, theoretical works on the promotion of resilience in developing countries point out quite rightfully that these activities boil down mainly to the introduction of Western practices, which does not contribute to the development of local resources, and therefore does not resolve the crisis, but only temporarily softens its impact (Bracket, 2016).

And yet, the European Union's promotion of resilience in neighboring countries represents a new political framework for existing initiatives rather than a totally new direction in cooperation. And there is more to it than just normative influence. Under the umbrella of resilience, the EU continues its policy of supporting market reforms, administrative innovations and environmental transformations. And this is where resilience is no more than just a vogue word rather than a concept, an attempt to find synonyms for such terms as 'stability' or 'sustainable development.' Nevertheless, this term creates the impression of a more all-embracive format for new cooperation, which is not limited to democratization, and also enables the EU to demonstrate better coordinated actions in the world and effective promotion of resilience through the implementation of projects launched earlier.

However, if we really think about the resilience of the post-Soviet space, the identification of its resources may indicate Russia's greater attractiveness. For example, an analysis of Belarus' or Moldova's economic ties shows that Russia and its domestic market appear to be more important for them than the EU as a potential importer of their products or labor. The same is true of cheap hydrocarbons and technologies, for example, in the nuclear power industry. Attempts by post-Soviet countries to diversify their markets, technological partners and employment opportunities for temporary migrants have proved unsuccessful so far. The complex system of technical and phytosanitary regulation, agricultural market protectionism, limited access to the labor market are real obstacles for Eastern European countries wishing to reorient their economy to the EU.

Interestingly, the elements the EU presents as incentives for rapprochement and potential resources for the economic resilience of 
neighborhood countries are already used by Russia. However, by all appearances, Russia can hardly become a serious opponent for the EU in a new round of geopolitical competition. The Kremlin's perception of the former Soviet space as periphery where Moscow is a normative leader by definition undermines its possibilities to use economic resources for consolidating cooperation and enhancing the resilience of its own system of interaction with neighboring countries. The European Union is obviously outplaying Russia in the normative field.

And yet, it will be wrong to say that tensions between Moscow and Brussels arose only after the Ukraine crisis of 2014. Problems have been piling up for years, and relations have been deteriorating since the beginning of the century along with changes in both Russia and the EU. However, in the past both occasionally took steps towards each other in an attempt to improve diplomatic contacts. Today, the search for a common solution has become extremely difficult.

The adoption by Brussels of the resilience concept, which in many ways focuses on Russia's foreign policy as a challenge not only to the EU but also the entire region, has exacerbated the situation. In fact, Brussels is articulating its new norm in response to the foreign policy course the Kremlin has been steering in recent years. While expressing its intention to pursue a more realistic policy and readiness to maintain its status in international relations, Brussels is also emphasizing the desire to spread its norms. Resilience is designed to fulfill these tasks. It serves as a new umbrella term under which the EU is consolidating its foreign and domestic policy initiatives.

In the meantime, Brussels is toughening its rhetoric, portraying Russia not just as an object of criticism, but as an actor that resists the European Union's normative aspirations, as the "Other." This contradistinction plays a special role in the post-Soviet space. Resilience is becoming a new instrument of geopolitical rivalry in this region where the EU is unable to move from the normative level to concrete realities, while Russia, which ensures the economic resilience of many countries in the area, is having trouble converting it into normative resilience. 
By entering a new stage in stigmatizing Russia as the "Other" through the concept of resilience, the European Union almost completely denies Moscow the chance to make new proposals on how to resolve tensions. Brussels is only prepared to dictate its own conditions for resuming talks, which means that no one else but it can initiate them. The branding of Russia as the "Other," that is, its exclusion from the European security system, essentially makes it impossible to use resilience as an instrument for overcoming the current crisis, even though in its academic interpretation resilience as a concept could become a tool for renewing cooperation between Russia and the EU. Moreover, over the years of their partnership, both sides have built up a significant stock of grassroots cooperation practices that could serve as the basis for strengthening the resilience of the EU-Russia relationship. It is also obvious that the resilience of each of them is a guarantee of security in the Greater Europe region.

The current situation requires serious concessions on both sides. For Russia, this is a normative field where it can hardly offer alternatives to Western values and thus challenge Brussels' leadership. As long as Russia is viewed as the "Other," this is unlikely, as any of its initiatives will be considered through the lens of securitization and resilience as a new EU norm.

The concept of resilience, as presented by European officials, is becoming an obstacle rather than an instrument for overcoming the crisis between Russia and the European Union. The normative leadership claimed by the EU suggests that it should take the first step in resolving the crisis, but Brussels is in no hurry and, on top of it all, lacks a coherent long-term concept of interaction. The European Union will also have to acknowledge that Russia, too, has significant material resources for resilience, including in the region of common neighborhood. Russia has no choice but wait for these steps to be taken.

\section{References}

Bakker, Y.W., de Koning, J. and van Tatenhove, J., 2019. Resilience and Social Capital: The Engagement of Fisheries Communities in Marine Spatial Planning. Marine Policy, 99, pp. 132-139. 
Bollig, M. and Anderson, D.M. (ed.), 2018. Resilience and Collapse in African Savannahs. Causes and Consequences of Environmental Change in East Africa. Abingdon, New York: Routledge.

Bourbeau, Ph., 2013. Resiliencism: Premises and Promises in Securitisation Research. Resilience, 1(1), pp. 3-17.

Bracke, S., 2016. Is the Subaltern Resilient? Notes on Agency and Neoliberal Subjects. Cultural Studies, 30(5), pp. 839-855.

Brassett, J., Croft, S. and Vaughan-Williams, N., 2013. Introduction: An Agenda for Resilience Research in Politics and International Relations. Politics, 33(4), pp. 221-228.

Coaffee J. and Fussey P., 2015. Constructing Resilience through Security and Surveillance: The Politics, Practices and Tensions of Security-Driven Resilience. Security Dialogue, 46(1), pp. 86-105.

Global Strategy, 2016: High Representative of the Union for Foreign Affairs and Security Policy. Shared Vision, Common Action: A Stronger Europe. A Global Strategy for the European Union's Foreign and Security Policy. Brussels: European Union External Action Service [online]. Available at: http://eeas.europa.eu/ archives/docs/top_stories/pdf/eugs_review_web.pdf [Accessed 11 April 2019]. Gudalov, N.N. and Tulupov, D.S., 2018. Semiotika stressoustoychivosti $\mathrm{v}$ mezhdunarodnyh otnosheniyah: mnogoobrazie akademicheskih i politicheskih smyslov [The Semiotics of Resilience in International Affairs: Diversity of Academic and Political Meanings]. Politia: Analiz. Khronika. Prognoz, 1 (88), pp. 135-147.

Holling, C. S., 1973. Resilience and Stability of Ecological Systems. Annual Review of Ecology and Systematics, 4(1), pp. 1-23.

Human Ecology, 2018, 46 (3). Special Issue.

Joseph, J., 2013. Resilience as Embedded Neoliberalism: A Governmentality Approach. Resilience. International Policies, Practices and Discourses, 1(1), pp. 38-52. Juncos A.E., 2016. Resilience as the New EU Foreign Policy Paradigm: A Pragmatist Turn? European Security, 26(1), pp.1-18.

Juncos, A., 2018. Resilience in Peacebuilding: Contesting Uncertainty, Ambiguity, and Complexity. Contemporary Security Policy, 39(4), pp. 559-574.

Krüger M., 2019. Building Instead of Imposing Resilience: Revisiting the Relationship Between Resilience and the State. International Political Sociology, 13(1), pp. 53-67. 
Li, C., 2012. The End of the CCP's Resilient Authoritarianism? A Tripartite Assessment of Shifting Power in China. The China Quarterly, 211, pp. 595-623.

Mavelli, L., 2017. Governing the Resilience of Neoliberalism through Biopolitics. European Journal of International Relations, 23(3), pp. 489-512.

Mogherini, F., 2016. Remarks by High Representative/Vice-President Federica Mogherini at the press conference following the Foreign Affairs Council. 14 March, Brussels, [online]. Available at: https://eeas.europa.eu/headquarters/ headquarters-homepage/5490/remarks-by-high-representativevice-presidentfederica-mogherini-at-the-press-conference-following-the-foreign-affairscouncil_en [Accessed 11 April 2019].

Nathan, A. J, 2003. Authoritarian Resilience. Journal of Democracy, 14 (1), pp. 6-17.

Pavlova, E.B. and Romanova, T.A, 2017. Normativnaya sila: teoria i praktika Rossii i ES [Normative Power: Theory and Practice of Russia and the EU]. Polis, 1, pp. 162-176.

Personal Interview, 2018. Lichoe Intervyu, October, Brussels.

Rogers P., 2013. Rethinking resilience: Articulating community and the UK riots. Politics, 33(4), pp. 322-333.

Romanova, T.A., 2017. Kategoria "stressoustoichivost" v Evropeiskom Soyuze [The Category of "Resilience" in the European Union]. Sovremennaya Evropa, No. 5, pp. 17-28.

Strategic Approach to Resilience, 2017: European Commission and European External Action Service. Joint Communication to the European Parliament and the Council. A Strategic Approach to Resilience in the EU's external action. JOIN 21 final. Brussels: European Commission and European External Action Service. 7 June [online]. Available at: https://eeas.europa.eu/sites/eeas/files/ join_2017_21_f1_communication_from_commission_to_inst_en_v7_ p1_916039.pdf [Accessed 11 April 2019].

Tocci, N., 2016. The Making of the EU Global Strategy. Contemporary Security Policy, 37(3), pp. 461-472.

Trechshenkov, Ye.Yu., 2019. Stressoustoichivost' v diskursah Evropeiskogo Soyuza i mezhdunarodnyh organizatsyi [Resilience on in the Discourse of the European Union and International Organizations]. Vestnik mezhdunarodnyh organizatsyi, 14(1), pp. 55-75. 